American Journal of Agricultural and Biological Sciences 4 (3): 249-254, 2009

ISSN 1557-4989

(C) 2009 Science Publications

\title{
A Simulation Model Estimates of the Intercropping Advantage of an Immature-Rubber, Banana and Pineapple System
}

\author{
${ }^{1}$ Mohamadu Boyie Jalloh, ${ }^{2}$ Wan Sulaiman Wan Harun, ${ }^{3}$ Jamal Talib, ${ }^{4}$ Mohd Fauzi Ramlan, \\ ${ }^{5}$ Rajan Amartalingam, ${ }^{3}$ Christopher Teh Boon Sung and ${ }^{5}$ Osumanu Haruna Ahmed \\ ${ }^{1}$ School of Sustainable Agriculture, University Malaysia Sabah, \\ Locked Bag 2073, 88999 Kota Kinabalu, Sabah, Malaysia \\ ${ }^{2}$ Department of Plant Science and Environmental Ecology, Faculty of Resource Science and Technology, \\ University Malaysia Sarawak, 94300 Kota Samarahan, Sarawak, Malaysia \\ ${ }^{3}$ Departments of Land Management, University Putra Malaysia, 43400 Serdang, Selangor, Malaysia \\ ${ }^{4}$ Crop Science Faculty of Agriculture, University Putra Malaysia, 43400 Serdang, Selangor, Malaysia \\ ${ }^{5}$ Department of Crop Science, Faculty of Agriculture and Food Science, University Putra Malaysia \\ Bintulu Campus, Sarawak, 97008 Bintulu, Sarawak, Malaysia
}

\begin{abstract}
Problem statement: Intercropping has been shown to have many advantages but it is fallacious to conclude it is always a better cropping system. Little is known about a new doublehedgerow intercropping of rubber, banana and pineapple in relation to its effects on growth and yield of the component crops when compared to their monocrops. Simulation modeling offers a cheaper and faster alternative to explore cropping scenarios and estimate their productivity under a wide range of management and environmental conditions. This simulation study was therefore undertaken to evaluate the growth and yield of immature rubber, banana and pineapple intercrop and monocrop scenarios with the aid of an intercrop simulation model named SURHIS, as well as estimating the intercropping advantage. Approach: A FORTRAN computer model (SURHIS) that simulated the daily light interception and utilization by immature-rubber, banana and pineapple intercropping system was used to simulate intercrop and monocrop scenarios to estimate potential Dry Matter Yield (DMY) for all crops as well as fruit yields for banana and pineapple. The results of the model were tested for accuracy by comparing actual field experimental results with the aid of Mean Deviation (MD) and Mean Absolute Error (MAE) statistical analyses. Intercropping advantage was assessed using the Land Equivalent Ratio (LER) analysis. Results: The model was representative or predicted DMY of the crops with sufficient accuracy. The LER analysis showed that the intercropping system had a dry matter yield productivity advantage of $81 \%$ more than monocrops of the component crops. The results also showed that the higher the Plant Population Density (PPD), the greater is the dry matter yield. It was also shown that banana and pineapple had no deleterious effect on the growth of rubber. Fruit weight per plant of banana and pineapple was reduced with increase in PPD for the monocrops. Measured average fresh fruit bunch weight for banana was $18 \mathrm{~kg} \mathrm{plant}^{-1}$ and the average fresh fruit weight per plant for pineapple was $2.1 \mathrm{~kg}$ for the intercropping system. Conclusion: Intercropping of banana and pineapple with immature-rubber is more productive than the component crops grown as monocrops in their respective optimum plant population densities per hectare. The model can be useful for predicting potential productivity, with sufficient accuracy, of the afore-mentioned intercropping system under varying plant density and environment scenarios as well as acting as a guide for plant density experimentation.
\end{abstract}

Key words: Intercropping advantage, rubber, banana, pineapple, simulation model, SURHIS

\section{INTRODUCTION}

To understand and integrate the complex myriad of processes in agronomic production systems, systems approaches have been developed to help in the studies that are usually involved. This approach involves the systematic and quantitative analysis of agricultural systems and synthesis of their comprehensive

Corresponding Author: Osumanu Haruna Ahmed, Department of Crop Science, Faculty of Agriculture and Food Sciences, University Putra Malaysia Bintulu Campus, Sarawak, Malaysia Tel: +6086855406 Fax: +608685415 
functional concepts. Many specific techniques can be used in this approach, which include simulation modeling, expert systems, databases, linear programming and Geographic Information Systems (GIS $)^{[1]}$.

There is established knowledge, although not in all cases, that intercrops usually do better than monocrops in terms of crop productivity ${ }^{[2]}$. This study presents the case of banana and pineapple intercropped with immature-rubber double-hedgerow to quantify their dry matter and fruit yield in intercrop and monocrop scenarios using a simulation model.

Assessing optimum biological productivity of different cropping systems for management recommendations to farmers on a national or regional basis could involve numerous site-specific fieldexperimentation. This is due to the wide variation in soil and aerial environmental conditions that can exist within and between sites. Results from such experiments may be valid only for the site, season and time of the experiments and some results may take years to obtain and a costly exercise. This may also be costly. Simulation modeling of several proposed cropping systems in a few experimental locations can provide a more useful, quicker and less costly alternative approach. Once a working model has been developed, it can be used as a tool to simulate and or predict what may happen under a wide variety of management and environmental conditions ${ }^{[3]}$. An enormous effort to systematically evaluate a very broad range of experimental designs, site, density and fertilizer options for maize and soybean intercropping has been done by some researchers ${ }^{[4]}$. They concluded that the complex interactions were very difficult to handle for the purpose of general recommendations. However, predictive extrapolation for other locations and seasons is now possible with the aid of simulation models and a large number of simulation models have been developed to extrapolate the results of experimental field studies ${ }^{[5-7]}$. The usefulness of simulation modeling cannot be more emphasized. This possibility was explored and made use of to obtain the results presented here.

When crops are grown in combination, it is apparent that there will be much more carbon being fixed in plant biomass per unit land area in comparison to a component monocrop because of much more leaf area coverage per unit land area. However, in addition to total biomass production, it is also important to consider the effects of the combinations on individual crop biomass and economic yield.

This study considered solar radiation as the crucial environmental factor that influences dry matter production. Crop productivity is based on the fact that Photosynthetically Active Radiation (PAR) energy is converted in a large scale into chemical energy stores in crops. This is a basis on which potential yields of a crop grown in a particular environment can be estimated. Therefore, in potential growth conditions, the judicious spatial and temporal management of crops for optimum utilization of valuable incident radiation by crops is important to minimize unrecoverable temporal waste of incident radiation.

Intercropping systems of trees and crops have their own special characteristics compared to crop-crop intercropping. For the resource radiation, a situation usually exists whereby the trees dominate the understorey crops except when all the component crops are young or of comparable heights. This means that the taller trees will always intercept incoming radiation first and only that transmitted will be available to the shorter crops $^{[8]}$. This poses a serious problem if crops that require high incident radiation are intercropped with trees. It is important therefore to give serious consideration to the proximity of the crops to the trees when practicing intercropping as well as their growth patterns.

Though there is a plethora of models ranging from those for annual crops to long-lived trees with varying model characteristics, they all remarkably have an overall similarity in structure ${ }^{[9]}$. This prompted crop growth modelers across the globe to mobilize their resources with the aim of developing models using a modular modeling approach and a common computer programming language FORTRAN ${ }^{[10]}$.

A model named SURHIS ${ }^{[1]}$ (Sharing and Utilization of Radiation intercepted in a HedgerowIntercropping System) based on SUCROS $1^{[12]}$ was developed from a rubber model ${ }^{[13]}$ and ALOHA $^{[14]}$ pineapple model. This model was then used to undertake this simulation study to evaluate the growth and yield of double-hedgerow immature-rubber, banana and pineapple intercrop and monocrop scenarios, as well as the intercropping advantage.

\section{MATERIALS AND METHODS}

The SURHIS model, which simulates daily light interception and utilization by immature-rubber, banana and pineapple intercropping system was used to simulate intercrop and monocrop scenarios to estimate Dry Matter Yield (DMY) for all crops as well as fruit yields for banana and pineapple. The model was written in FORTRAN using the Fortran Simulation Environment (FSE) software ${ }^{[15]}$. Results of the model are output on a daily basis and the model assumes that water and 
nutrients are non-limiting and the crops are free of pests and diseases. Only temperature, radiation, crop morphphysiology and Plant Population Density (PPD) are considered as influencing factors in the cropping system. This means potential growing conditions.

Light interception was quantified using a modified beer's law ${ }^{[16,17]}$ as shown in equation 1a and fractional interception approach ${ }^{[18]}$ as shown in Eq. 2:

$$
\mathrm{A}_{\mathrm{T}}=\mathrm{I}_{0} \exp \left(-\sum_{\mathrm{i}=1}^{\mathrm{n}} \mathrm{k}_{\mathrm{i}} \Omega \mathrm{L}_{\mathrm{i}}\right)
$$

$\mathrm{A}_{\mathrm{T}}=$ Total intercepted radiation by all crops $\mathrm{m}^{-2} \mathrm{sec}^{-1}$ )

$\mathrm{I}_{0}=$ Incident radiation above crop canopy $\left(\mathrm{J} \mathrm{m}^{-2} \mathrm{sec}^{-1}\right)$

$\mathrm{K}_{\mathrm{i}}=$ Radiation extinction coefficient of crop species $\mathrm{i}$

$\Omega=$ Clump factor ${ }^{[17]}$

$\mathrm{L}_{\mathrm{i}}=\mathrm{LAI}$ of crop species $\mathrm{i}$ :

$$
F_{i}=\left(\frac{k_{i} L_{i} h_{i}}{\sum_{j=1}^{n} k_{j} L_{j} h_{j}}\right) \cdot A_{T}
$$

$\mathrm{F}_{\mathrm{i}}=$ Fractional interception by crop species $\mathrm{i}$ and $\left(\mathrm{J} \mathrm{m}^{-2}\right.$ $\sec ^{-1}$ )

$h_{i}=$ Height of species $i(m)$

Dry matter was quantified in the model based on the difference between carbon assimilation from photosynthesis and respiratory losses due to metabolic and growth processes (Eq. 3 and 4):

$$
\begin{aligned}
& \partial \mathrm{DM}_{\mathrm{v}} / \partial \mathrm{t}=\mathrm{E}_{\mathrm{v}} \mathrm{VDM}_{\mathrm{C}} \\
& \partial \mathrm{DM}_{\mathrm{Y}} / \partial \mathrm{t}=\mathrm{E}_{\mathrm{Y}}\left(\mathrm{A}-\mathrm{R}-\mathrm{VDM}_{\mathrm{C}}\right)
\end{aligned}
$$

$\mathrm{DM}_{\mathrm{V}}=$ Vegetative dry matter

$\mathrm{E}_{\mathrm{V}} \quad=$ Conversion efficiency for $\mathrm{DM}_{\mathrm{V}}$

$\mathrm{VDM}_{\mathrm{C}}=\mathrm{CH}_{2} \mathrm{O}$ requirement for Daily VDM Growth

$\mathrm{DM}_{\mathrm{Y}}=$ Yield dry matter

$\mathrm{EY}_{\mathrm{Y}}=$ Conversion efficiency from $\mathrm{CH}_{2} \mathrm{O}$ to Yield

A = Canopy gross photosynthesis rate $\left(\mathrm{kg} \mathrm{CH}_{2} \mathrm{O}\right.$ $\mathrm{ha}^{-1}$ day $^{-1}$ )

$\mathrm{R}=$ Respiratory Losses $\left(\mathrm{kg} \mathrm{CH}_{2} \mathrm{O}, \mathrm{kg} \mathrm{DM}^{-1}\right.$ day $\left.^{-1}\right)$

$\mathrm{t} \quad=$ Time (day)

Fruit yield was quantified based on the fraction of remaining assimilates partitioned to the fruits after respiratory losses have been subtracted. This fraction was determined by an empirical routine in the model, which is a function of the phenological stage of the crop.
The DMY results of the model was evaluated using results of a field experiment conducted at University Putra Malaysia (UPM) $\left(3^{\circ} 02^{\prime} \mathrm{N}\right.$ and $101^{\circ} 42^{\prime} \mathrm{E} ; 31 \mathrm{~m}$ above sea level) using the Mean Absolute Error (MAE) and Mean Deviation (MD) analysis ${ }^{[19,20]}$ shown as Eq. 5 and 6 respectively.

Crop data for model evaluation was collected from a field plot in. The soil at this site was Typic Kandiudult and named Serdang series in the Malaysian soil nomenclature ${ }^{[21]}$.

Crop growth rate, which is the rate of dry matter production, was estimated for each crop using the functional approach ${ }^{[22]}$ from dry weigh measurements of the crops.

Weather data was from records of the weather station located about $50 \mathrm{~m}$ from the experimental plot. These data were used as input to run the simulations:

MAE $=\frac{\sum_{\mathrm{i}=1}^{\mathrm{n}}\left|\mathrm{Y}_{\mathrm{i}}-\mathrm{X}_{\mathrm{i}}\right|}{\mathrm{n}}$

$\mathrm{MD}=\frac{\sum_{\mathrm{i}=1}^{\mathrm{n}} \mathrm{Y}_{\mathrm{i}}-\mathrm{X}_{\mathrm{i}}}{\mathrm{n}}$

$\mathrm{n} \quad=$ Sample size

$\left|Y_{i}-X_{i}\right|=$ The absolute error term, where in $Y_{i}$ and $X_{i}$ are the ith predicted and observed values respectively

Intercropping advantage was determined using the Land Equivalent Ratio (LER) analysis ${ }^{[8]}$ for known PPD's of the intercropping system and compared to known optimum PPD's of monocrop scenarios:

$\operatorname{LER}=\sum_{\mathrm{j}=1}^{\mathrm{n}} \mathrm{y}_{\mathrm{j}, \mathrm{i}} / \mathrm{y}_{\mathrm{j}, \mathrm{s}}$

$\mathrm{y}_{\mathrm{j}, \mathrm{I}}=$ Yield of intercrop component crop j $\left(\mathrm{kg} \mathrm{h}^{-1}\right)$

$\mathrm{y}_{\mathrm{j}, \mathrm{s}}=$ Yield of mocrop component $\left(\mathrm{kg} \mathrm{h}^{-1}\right)$

$\mathrm{n}=$ Number of component crops

\section{RESULTS}

Generally, the model predicted DMY of the banana parent-crop accurately compared to field measurements with a MD of $8.7 \%$ and MAE of $11.1 \%$ as shown in Fig. 1. However, the model overestimated DMY after 150 Days After Planting (DAP). In the case of pineapple, the model generally predicted DMY accurately with a MD of $11.2 \%$ and MAE of $13 \%$ with overestimations 280 DAP (Fig. 2). 


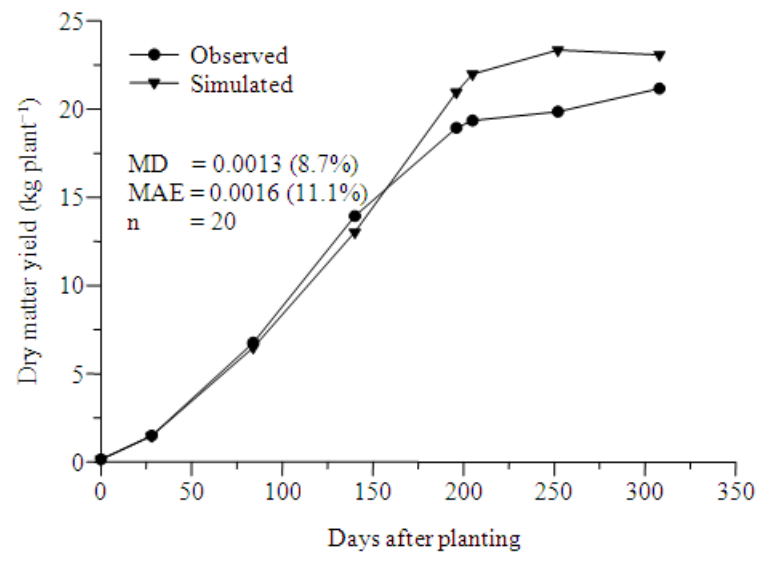

Fig. 1: The observed and simulated dry matter yield of banana parents plants for the UMP field plot

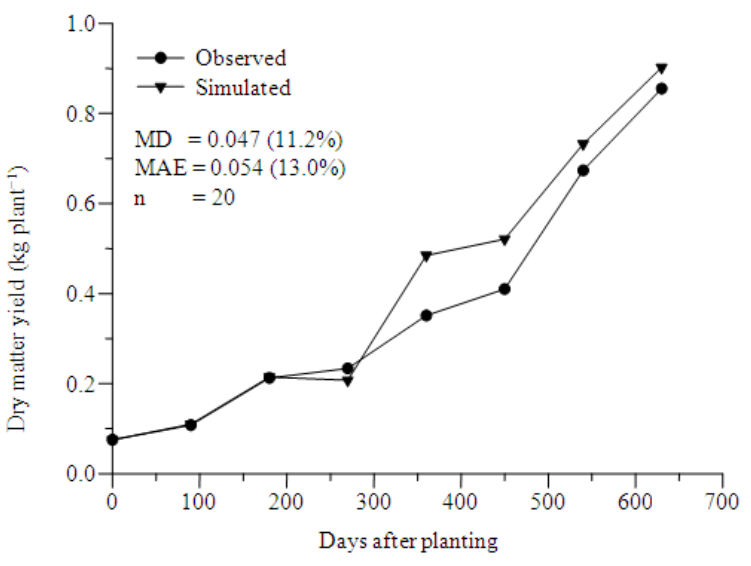

Fig. 2: The observed and simulated dry matter yield of pineapple plants for the UPM field plot

Table 1-3 show the results of DM yield for different cropping scenarios. From calculations based on the results shown in the tables, the total area of rubber, banana and pineapple monocultures needed to produce the equivalent of a single hectare of rubberbanana-pineapple intercrop is 1.81 , which is the LER.

This means the intercropping advantage in terms of land area used is $81 \%$ as shown in the calculations below:

$$
\begin{aligned}
\text { LER } & =\left(\frac{25.94}{25.97}+\frac{20.29}{27.92}+\frac{2.1}{23.22}\right) \text { ha } \\
& =0.99+0.73+0.09 \\
& =1.81 \mathrm{ha}
\end{aligned}
$$

The simulated DMY for rubber is equal (about $25.9 \mathrm{t} \mathrm{h}^{-1}$ ) at $265 \mathrm{DAP}$ for both intercrop and monocrop scenarios as shown in Table 3.
Table 1: The simulated potential DMY for up to 265 days after planting and FFW at harvest of banana for the UPM field plot for three cropping scenarios

\begin{tabular}{lllll}
\hline Crop system & PPD $\left(\mathrm{h}^{-1}\right)$ & DMY $\left(\mathrm{kg} \mathrm{h}^{-1}\right)$ & $\mathrm{FFW}\left(\mathrm{kg} \mathrm{h}^{-1}\right)$ & $\mathrm{FFW}\left(\mathrm{kg} \mathrm{plant}^{-1}\right)$ \\
\hline Mono-crop & 1680 & 27922 & 29232 & 17.40 \\
& 1800 & 28031 & 27684 & 15.38 \\
Inter-crop & 880 & 20292 & 16984 & 19.30 \\
\hline
\end{tabular}

Table 2: The simulated potential DMY for up to 265 days after planting and FFW at harvest of pineapple for the UPM field plot for three cropping scenarios

\begin{tabular}{lllll}
\hline Crop system & PPD $\left(\mathrm{h}^{-1}\right)$ & DMY $\left(\mathrm{kg} \mathrm{h}^{-1}\right)$ & $\mathrm{FFW}\left(\mathrm{kg} \mathrm{h}^{-1}\right)$ & $\mathrm{FFW}\left(\mathrm{kg} \mathrm{plant}^{-1}\right)$ \\
\hline Mono-crop & 50000 & 23218 & 94500 & 1.89 \\
& 55000 & 23738 & 66000 & 1.72 \\
Inter-crop & 7040 & 2048.1 & 15066 & 2.14 \\
\hline
\end{tabular}

Table 3: The simulated potential DMY for up to 265 days after planting of rubber for the UPM field plot for two cropping scenarios

\begin{tabular}{lll}
\hline Cropping system & PPD $\left(\mathrm{h}^{-1}\right)$ & $\mathrm{DMY}\left(\mathrm{kg} \mathrm{h}^{-1}\right)$ \\
\hline Mono-crop & 485 & 25974 \\
Inter-crop & 485 & 25942 \\
\hline
\end{tabular}

Table 1 and 2 also show that variations in PPD have a relationship with DMY and fruit yield. The higher the PPD, the greater the DMY but the fruit weight per plant is reduced. Measured average fresh fruit bunch weight for banana was $18 \mathrm{~kg} \mathrm{plant}^{-1}$ and the average fresh fruit weight per plant for pineapple was $2.1 \mathrm{~kg}$.

\section{DISCUSSION}

In general, the model predicted banana DMY accurately with a MD of $8.7 \%$ MAE of $11.1 \%$ as shown in Fig. 1. However, the model overestimated DMY after 150 DAP. This could be due to the transition from vegetative to reproductive phase, during which some extra physiological processes causing more respiratory energy losses and hence DM loss, that is not accounted for by the model.

Figure 2 shows that the model generally predicted pineapple DMY with sufficient accuracy with a MD of $11.2 \%$ and MAE of $13.0 \%$. However, it overestimated DMY after 280 DAP. This could also be explained by, as the case of banana, the transition from vegetative to reproductive phase of the crop. Between 0.35-0.4 kg plant ${ }^{-1}$ DMY at 300 DAP was reported for Smooth cayenne in Mexico under different fertilizer regimes ${ }^{[23]}$. The results do not differ much for the observed and simulated values shown in Fig. 2, which is about 0.3 and $0.35 \mathrm{~kg} \mathrm{plant}^{-1}$, respectively. The results are also very similar to those measured and simulated using ALOHA ${ }^{[14]}$ under Hawaiian conditions.

Intercropping advantage has been illustrated in many forms, either in monetary economic terms, 
economic yield, biomass yield or dry matter yield. Land Equivalent Ratio (LER) or Relative Yield Total (RYT) is the more widely used concept, which is defined as the ratio of area needed under monoculture to a unit area of intercropping at the same management level to give and equal amount of yield $^{[8]}$. The simulated DMY for immature-rubber being equal (about $25.9 \mathrm{t} \mathrm{h}^{-1}$ ) at 265 DAP for both intercrop and monocrop scenarios as shown in Table 3 is indicative that the growth of the rubber crop is unaffected by association with banana and pineapple crops. At the same time the DMY advantage is about $81 \%$ in favor of the intercrop system.

It is also evident from Table 1 and 2 that PPD variations show a relationship with DMY and harvest index or fruit yield. The general trend is that the higher the PPD, the higher the DMY but the lower the fruit weight per plant. Measured average fresh fruit bunch weight for banana was $18 \mathrm{~kg} \mathrm{plant}^{-1}$ and the average fresh fruit weight per plant for pineapple was $2.1 \mathrm{~kg}$. It is clear that during the immature stages of rubber, short or medium term crops such as banana and pineapple can be grown as intercrops. However, there is a limit to the number of years during which such practice can successfully continue. This is primarily due to competition for resources. In conventional practice with rubber plant spacing of

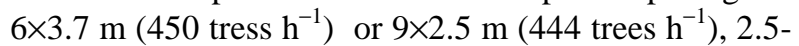
3 years have been recorded as the period when shading from rubber can have significant yield depressing effects on intercropped bananas. Observation shows that a 25.2 and $60.8 \%$ decline in intercropped banana yield in the 3rd and 4th years, respectively, under replanted rubber at a density of 444 trees $\mathrm{h}^{-1}$. This was associated with low radiation transmissions of 38 and $21 \%$ through the rubber canopies in the $3 \mathrm{rd}$ and 4th years respectively to the under-storey banana crops. This is reinforced by a study ${ }^{[24]}$ which indicated that an increase in planting density from single row to three rows of banana had no detrimental effect on growth and yield of either banana or rubber. Several successive ratoons of banana are possible until the rubber canopy inhibits the availability of incident radiation for the intercrop.

\section{CONCLUSION}

Intercropping of banana and pineapple with immature-rubber is more productive than the component crops grown as monocrops in their respective optimum PPD per hectare. In addition there was detrimental impact on rubber DMY from intercrops.
The model predicts DM and fruit yield with sufficient accuracy but there is still room for improvement where over-estimation occurs as well for expansion of the model to include water and nutrient balances for a more holistic system analysis.

The results indicate that the model can act as a guide to experiment on plant population density effects on yield for optimum combinations selection.

Careful study of the plant population density effects, especially on fruit yield per plant need to be researched further to be able to determine the optimum plant population density.

\section{ACKNOWLEDGEMENT}

The researchers acknowledge the financial support of this research through the Intensive Research in Priority Areas (IRPA) grant from the Ministry of Higher Education, Malaysia.

\section{REFERENCES}

1. Kropff, M.J., J. Bouma and J.W. Jones, 2001. Systems approaches for the design of sustainable agro-ecosystems. Agric. Syst., 70: 369-393. DOI: 10.1016/S0308-521X(01)00052-X

2. Willey, R.W., 1979. Intercropping-Its importance and research needs. Part competition and yield advantages. Field Crops Abstr., 32: 1-10. http://www.cababstractsplus.org/abstracts/Abstract. aspx?AcNo=19790783327

3. Fageria, N.K., V.C. Baligar and C.A. Jones, 1997. Growth and Mineral Nutrition of Field Crops. 2nd Edn., Marcel Decker, New York, ISBN: 0824700899, pp: 624.

4. Russell, J.T. and R.M. Caldwell, 1989. Effects of component densities and $\mathrm{N}$ fertilization on efficiency and yield of maize/soybean intercrop. Exp. Agric., 25: 529-540. DOI: 10.1017/S0014479700015155

5. Penning de Vries, F.W.T., D.M. Jansen, H.F.M. Ten Berge and A. Bakema, 1989. Simulation of Ecophysiological Processes of Growth in Several Annual Crops. Pudoc, Wageningen, Netherlands. ISBN: 9711042150, pp: 271.

6. Whisler, F.D., A. Acock, D.N. Baker, R.E. Fye and H.F. Hodges et al., 1986. Crop simulation models in agronomic systems. Adv. Agron., 40: 141-208. DOI: $10.1016 / S 0065-2113(08) 60282-5$

7. Ritchie, J.T., 1991. Specifications of the Ideal Model for Predicting Crop Yields. In: Climatic Risk in Crop Production: Models and Management for the Semiarid Tropics and Subtropics, Muchow, R.C. and J.A. Bellamy (Eds.). CAB International, ISBN: 085198665X, pp: 97-122. 
8. Vandermeer, J.H., 1989. The Ecology of Intercropping. Cambridge University Press, Cambridge, ISBN: 0521345928, pp: 237.

9. Reynolds, J.F. and B. Acock, 1985. Predicting the response of plants to increasing carbon dioxide: A critique of plant growth models. Ecol. Model., 29: 107-129. DOI: 10.1016/0304-3800(85)90049-3

10. Jones, J.W., B.A. Keating and C.H. Porter, 2001. Approaches to modular model development. Agric. Syst., 70: 421-443. DOI: 10.1016/S0308$521 \mathrm{X}(01) 00054-3$

11. Jalloh, M.B., 2003. Modeling of solar radiation interception and biomass production in an intercropping system of rubber with banana and pineapple. PhD Thesis, University Putra Malaysia. http://webopac.upm.edu.my

12. Goudriaan, J. and H.H. Van Laar, 1994. Modeling Potential Crop Growth Processes. A textbook with exercises. Current Issues in Production Ecology. Kluwer, Netherlands. ISBN: 0792332199, pp: 238.

13. Castro, A.M.G., 1988. A systems approach to determining priorities for natural rubber research in Brazil. PhD Thesis, University of Reading, UK. http://dino.wiz.unikassel.de/model_db/mdb/emb_rubber.html

14. Zhang, J. and D.P. Bartholomew, 1993. Simulation of pineapple growth, development and yield. Acta Hortic., 334: 205-219. http://www.actahort.org/books/334/334_21.htm

15. Kraalingen, D.W.G. van, 1995. The FSE System for Crop Simulation, Version 2.1. Quantitative Approaches in Systems Analysis; No.1. AB-DLO, Wageningen: The CT de Wit Graduate School of Production Ecology, ISBN: 9073384346, pp: 70.

16. Monsi, M. and T. Saeki, 1953. Über den Lichtfaktor in den Pflanzengesellschaften und seine Bedeutung für die Stoffproduktion. (Abstract in English) Jap. J. Bot., 14: 22-52. http://www.worldcat.org/wcpa/ow/1713922

17. Kustas, W.P. and J.M. Norman, 1999. Evaluation of soil and vegetation heat flux predictions using a simple two-source model with radiometric temperatures for partial canopy cover. Agric. For. Meteorol., 94: 13-29. DOI: 10.1016/S01681923(99)00005-2
18. Spitters, C.J.T., 1990. On Descriptive and Mechanistic Models for Inter-Plant Competition, with Particular Reference to Crop-Weed Interaction. In: Theoretical Production Ecology: Reflections and Prospects, Rabbinge, R., J. Goudriaan, H. Van Keulen, F.W.T. Penning de Vries and H.H. Van Laar (Eds.). Simulation Monographs 34, Pudoc, Wageningen, ISBN: 902201004X, pp: 217-236.

19. Malezieux, E., J. Zhang, E.R. Sinclair and D.P. Bartholomew, 1994. Predicting harvest date in different environments, using a computer simulation model. Agron. J., 86: 609-617. http://agron.scijournals.org/cgi/reprint/86/4/609

20. Wilson, D.R., R.C. Muchow and C.J. Murgatroyd, 1995. Model analysis of temperature and solar radiation limitations to maize potential productivity in a cool climate. Field Crops Res., 43: 1-18. DOI: 10.1016/0378-4290(95)00037-Q

21. Paramananthan, S., 2000. Soils of Malaysia: Their Characteristics and Identification. Academy of Sciences Malaysia, Kuala Lumpur, ISBN: 9839445065.

22. Hunt, R., 1982. Plant growth curves. The Functional Approach to Plant Growth Analysis. Edward-Arnold, London, ISBN: 0713128445, pp: 248.

23. Rebolledo-Martinez, A., K.R. Mosqueda-Vazequet, A.E. Becerril-Roman, L. Rebolledo-Martinez and D.E. Uriza-Avila, 1993. Growth analysis of smooth cayenne pineapple grown under four fertlizer rates in Veracruz, Mexico. Acta Hortic., 334: 159-169. http://www.actahort.org/books/334/334_16.htm

24. Rodrigo, V.H.L., C.M. Stirling, Z. Teklehaimanot and A. Nugawela, 1997. The effect of planting density on growth and development of component crops in rubber/banana intercropping systems. Field Crops Res., 52: 95-108. DOI: 10.1016/S0378-4290(96)01069-6 